\title{
Formulasi dan Karakterisasi Buccal Film Salbutamol Sulfat
}

\author{
Devita Suba Mairi*, Ismar Wulan, Lili Handayani
}

Fakultas Farmasi Universitas Halu Oleo, Kampus Hijau Bumi Tridharma Anduonohu Jl. H. E. A. Mokodompit Kendari 93232

\begin{abstract}
Abstrak
Buccal film merupakan salah satu sistem penghantaran obat melalui jaringan rongga mulut. Mukosa bukal memiliki aksesibilitas yang sangat baik, yang menyebabkan akses langsung ke sirkulasi sistemik melalui vena jugularis internal yang dilewati obatobatan dari metabolisme pertama di kelenjar hati. Penelitian ini bertujuan untuk memformulasikan sediaan buccal film salbutamol sulfat, dan mengetahui karakteristik sediaan buccal film salbutamol sulfat, serta mengetahui pelepasan in vitro sediaan buccal film salbutamol sulfat. Buccal film salbutamol sulfat dibuat dengan variasi perbandingan HPMC K15M:Na.CMC yaitu 1:2, 1:1 dan 2:1. Semua formula memiliki karakterisasi yang tidak jauh berbeda yaitu transparan, memiliki daya tahan lipat yang ideal serta $\mathrm{pH}$ yang sesuai.
\end{abstract}

Kata kunci: buccal film, salbutamol sulfat, HPMC, in vitro

\section{Pendahuluan}

Asma adalah gangguan kompleks yang didefinisikan sebagai penyakit heterogen dan biasanya ditandai dengan peradangan saluran napas. Peradangan ini menyebabkan keterbatasan aliran udara sehingga menimbulkan mengi, sesak napas, sesak dada, dan batuk, terutama pada malam atau dini hari [1]. Salah satu penelitian pada tahun 2012 menyoroti bahwa asma yang terus menjadi perhatian utama kesehatan masyarakat di seluruh dunia [2]. Penerapan prevalensi klinis asma sebanyak $8,6 \%$ pada populasi dunia sebesar 7 miliar saat ini, maka diperkirakan bahwa hampir 623 juta orang hidup dengan beberapa tingkat gejala terkait asma, dan menyebabkan 180.000 kematian di seluruh dunia setiap tahunnya [3]. Berdasarkan data dari Riset Kesehatan Dasar, diperoleh data kasus asma di Indonesia mencapai 4,5\% dari seluruh penduduk [4].

Salah satu obat yang paling luas digunakan untuk mengobati asma saat ini adalah salbutamol sulfat ${ }^{[5]}$. Salbutamol sulfat merupakan golongan agonis adrenoseptor $\beta_{2}$-selektif dengan efek kerja pendek yang paling aman dan paling efektif, serta digunakan sebagai pilihan pertama dalam penanganan penyakit asma $[6,7]$. Salbutamol sulfat memiliki waktu paruh yang relatif pendek dan bioavailabilitas yang rendah [8]. Bila diberikan secara oral, bioavailabilitas sistemiknya hanya $50 \%$ karena mengalami metabolisme lintas pertama di hati dan metabolisme presistemik yang luas terutama karena sulfasi pada mukosa duodenum, dengan waktu paruh plasma salbutamol diperkirakan berkisar antara 4 sampai 6 jam. Sedangkan pemberian dengan inhalasi hanya $10-20 \%$ dosis obat yang mencapai saluran napas bagian bawah $[9,10]$.

Sistem penghantaran obat melalui rute bukal menawarkan beberapa keuntungan bila dibandingkan dengan sediaan oral dan pemberian secara inhalasi dari salbutamol sulfat, antara lain mengurangi dosis secara signifikan, mempertahankan kadar darah tunak untuk waktu yang lebih lama, memberikan bioavailabilitas yang lebih baik dengan menghindari metabolisme lintas pertama dan lebih banyak fraksi obat masuk ke sirkulasi sistemik [11]. Oleh karena itu, penelitian ini dilakukan untuk memformulasikan dan meningkatkan bioavailabilitas salbutamol sulfat sebagai pengobatan asma yang sering diresepkan bagi pasien gangguan inflamasi kronis pada saluran napas sebagai sistem penghantaran buccal film.

\section{Bahan dan Metode}

\subsection{Pembuatan Buccal Film}

Buccal film mukoadhesif dipreparasi dengan menggunakan metode solvent casting. Sejumlah salbutamol sulfat, HPMC K15M dan Na.CMC dilarutkan dengan menggunakan akuades dalam wadah terpisah dan diaduk menggunakan magnetic stirrer. Setelah terdispersi homogen, larutan polimer dan larutan

\footnotetext{
*Email : 19devita.suba@gmail.com
} 
salbutamol sulfat dicampur dan diaduk hingga homogen. Kemudian gliserin sebagai plasticizer dan tween 80 sebagai peningkat penetrasi dicampurkan ke dalam larutan tersebut dan diaduk homogen dengan bantuan magnetic stirrer. Larutan dituang ke dalam cetakan dan dikeringkan pada suhu $60^{\circ} \mathrm{C}$ dalam oven selama 18 jam hingga film terbentuk. Setelah kering, film dipotong dengan ukuran $1 \times 1 \mathrm{~cm}^{2}$ menggunakan cutter atau scalpel steril [12]

Tabel 1. Rancangan formula sediaan buccal film

\begin{tabular}{|c|c|c|c|c|}
\hline Bahan & Fungsi & F1 & F2 & F3 \\
\hline $\begin{array}{l}\text { Salbutamol Sulfat } \\
(\mathrm{mg})\end{array}$ & Zat Aktif & $4 \mathrm{~g}$ & $4 \mathrm{~g}$ & $4 \mathrm{~g}$ \\
\hline $\begin{array}{l}\text { HPMC K15M } \\
(\mathrm{mg})\end{array}$ & Polimer & $\begin{array}{c}0,67 \\
\mathrm{mg}\end{array}$ & $\begin{array}{l}0,5 \\
\mathrm{mg}\end{array}$ & $\begin{array}{c}0,33 \\
\mathrm{mg}\end{array}$ \\
\hline Na. CMC (mg) & Polimer & $\begin{array}{c}0,33 \\
\mathrm{mg}\end{array}$ & $\begin{array}{l}0,5 \\
\mathrm{mg}\end{array}$ & $\begin{array}{c}0,67 \\
\mathrm{mg}\end{array}$ \\
\hline Tween $80(\mathrm{~mL})$ & $\begin{array}{l}\text { Chemical } \\
\text { Enhancer }\end{array}$ & $\begin{array}{c}15 \\
\text { tetes }\end{array}$ & $\begin{array}{c}15 \\
\text { tetes }\end{array}$ & $\begin{array}{c}15 \\
\text { tetes }\end{array}$ \\
\hline Gliserin (mL) & Plasticizer & $\begin{array}{l}15 \\
\text { tetes }\end{array}$ & $\begin{array}{c}15 \\
\text { tetes }\end{array}$ & $\begin{array}{c}15 \\
\text { tetes }\end{array}$ \\
\hline Air Suling (mL) & Pelarut & q.s. & q.s. & q.s. \\
\hline
\end{tabular}

\subsection{Karakterisasi Sediaan Buccal Film}

\section{Keseragaman Ketebalan Film}

Ketebalan setiap film diukur dengan menggunakan kaliper vernier pada empat posisi film yang berbeda dan rata-rata dihitung.

\section{Daya Tahan Lipat}

Daya tahan lipatan film ditentukan dengan melipat berulang kali satu tempat di tempat yang sama sampai pecah atau dilipat hingga 300 kali secara manual, yang dianggap memuaskan untuk mengungkapkan sifat film yang baik.

\section{Keseragaman Berat Film}

Ukuran film dipotong $1 \times 1 \mathrm{~cm}^{2}$. Bobot lima film diambil dan variasi berat dihitung.

\section{pH Permukaan}

Pengujian $\mathrm{pH}$ permukaan film dilakukan dengan cara merendam film dengan $20 \mathrm{ml}$ dapar fosfat $\mathrm{pH}$ 6,8 dalam cawan petri selama 1 jam [13]. Nilai $\mathrm{pH}$ permukaan kemudian diukur dengan menggunakan kertas indikator $\mathrm{pH}$ yang ditempatkan pada permukaan film yang mengembang.

\section{Hasil dan Pembahasan}

Hasil formulasi buccal film memperlihatkan ketebalan dari film yang dihasilkan cukup seragam (Tabel 1). Pengujian daya tahan lipatan film ditentukan dengan cara melipat secara berulang satu film pada tempat yang sama hingga patah atau dilipat hingga 300 kali secara manual. Hasil pengujian menunjukkan bahwa setiap formula memiliki daya tahan lipat lebih dari 300 kali pada tempat yang sama karena lapisan film yang dihasilkan sangat lentur dan tidak kaku (Tabel 2)

Tabel 1. Uji ketebalan buccal film

\begin{tabular}{|c|c|c|c|c|c|c|}
\hline \multirow{2}{*}{\multicolumn{2}{|c|}{ Formula }} & \multicolumn{5}{|c|}{ Ketebalan Film $(\mu \mathrm{m})$} \\
\hline & & $\begin{array}{c}\text { Titik } \\
1\end{array}$ & $\begin{array}{c}\text { Titik } \\
2\end{array}$ & $\begin{array}{c}\text { Titik } \\
\mathbf{3}\end{array}$ & $\begin{array}{c}\text { Titik } \\
4\end{array}$ & $\begin{array}{c}\text { Rata- } \\
\text { rata }\end{array}$ \\
\hline \multirow{5}{*}{ F1 } & 1 & 340 & 340 & 340 & 320 & 335 \\
\hline & 2 & 340 & 340 & 320 & 320 & 330 \\
\hline & 3 & 340 & 340 & 340 & 340 & 340 \\
\hline & \multicolumn{5}{|c|}{ Rata-rata } & 335 \\
\hline & \multicolumn{5}{|c|}{ SB } & 5 \\
\hline \multirow{5}{*}{ F2 } & 1 & 300 & 320 & 320 & 320 & 315 \\
\hline & 2 & 320 & 320 & 320 & 320 & 320 \\
\hline & 3 & 300 & 300 & 320 & 300 & 305 \\
\hline & \multicolumn{5}{|c|}{ Rata-rata } & 313 \\
\hline & \multicolumn{5}{|c|}{ SB } & 7,64 \\
\hline \multirow{5}{*}{ F3 } & 1 & 400 & 420 & 420 & 420 & 415 \\
\hline & 2 & 420 & 400 & 400 & 420 & 410 \\
\hline & 3 & 400 & 400 & 400 & 400 & 400 \\
\hline & \multicolumn{5}{|c|}{ Rata-rata } & 408 \\
\hline & \multicolumn{5}{|c|}{ SB } & 7,64 \\
\hline
\end{tabular}

Tabel 2. Uji daya tahan lipat buccal film

\begin{tabular}{|c|c|c|c|c|c|c|c|}
\hline \multirow{2}{*}{\multicolumn{2}{|c|}{ Formula }} & \multicolumn{6}{|c|}{ Bobot Film (mg) } \\
\hline & & 1 & 2 & 3 & 4 & 5 & $\begin{array}{c}\text { Rata- } \\
\text { rata }\end{array}$ \\
\hline \multirow{5}{*}{ F1 } & 1 & 38,0 & 38,9 & 39,7 & 36,0 & 38,6 & 38,2 \\
\hline & 2 & 39,0 & 41,0 & 38,0 & 41,1 & 37,9 & 39,4 \\
\hline & 3 & 35,6 & 35,0 & 38,6 & 37,9 & 35,2 & 36,5 \\
\hline & \multicolumn{6}{|c|}{ Rata-rata } & 38,0 \\
\hline & \multicolumn{6}{|c|}{ SB } & 1,46 \\
\hline \multirow{5}{*}{ F2 } & 1 & 32,1 & 33,5 & 32,7 & 32,8 & 34,9 & 33,2 \\
\hline & 2 & 34,1 & 32,2 & 33,0 & 35,0 & 34,7 & 33,8 \\
\hline & 3 & 32,5 & 35,1 & 35,6 & 36,0 & 33,5 & 34,5 \\
\hline & \multicolumn{6}{|c|}{ Rata-rata } & 33,8 \\
\hline & \multicolumn{6}{|c|}{ SB } & 0,65 \\
\hline \multirow{5}{*}{ F3 } & 1 & 41,0 & 41,1 & 42,0 & 39,7 & 39,0 & 40,6 \\
\hline & 2 & 42,5 & 46,2 & 42,2 & 42,3 & 42,0 & 43,0 \\
\hline & 3 & 41,1 & 42,0 & 42,3 & 41,6 & 42,5 & 41,9 \\
\hline & \multicolumn{6}{|c|}{ Rata-rata } & 41,8 \\
\hline & \multicolumn{6}{|c|}{ SB } & 1,20 \\
\hline
\end{tabular}

Karakteristik film dapat dilihat pada Tabel 3. Hasil data diketahui bahwa film yang dihasilkan memiliki keragaman bobot yang cukup seragam. Selain itu, $\mathrm{pH}$ permukaan film yang diukur menggunakan $\mathrm{pH}$ indikator 
Tabel 3. Uji daya tahan lipat dan $\mathrm{pH}$ permukaan

\begin{tabular}{|c|c|c|c|c|c|c|c|c|}
\hline \multirow{2}{*}{ Formula } & \multicolumn{3}{|c|}{ Daya Tahan Lipat } & \multirow{2}{*}{ Rata-rata } & \multicolumn{3}{|c|}{ pH Permukaan } & \multirow{2}{*}{ Rata-rata } \\
\hline & 1 & 2 & 3 & & 1 & 2 & 3 & \\
\hline F1 & $>300$ & $>300$ & $>300$ & $>300$ & 7 & 7 & 7 & 7 \\
\hline F2 & $>300$ & $>300$ & $>300$ & $>300$ & 7 & 7 & 7 & 7 \\
\hline F3 & $>300$ & $>300$ & $>300$ & $>300$ & 7 & 7 & 7 & 7 \\
\hline
\end{tabular}

universal memperlihatkan $\mathrm{pH}$ permukaan dari setiap formula memiliki $\mathrm{pH}$ netral yaitu 7. Hasil pengukuran ini diharapkan film tidak menimbulkan iritasi pada mukosa gusi. $\mathrm{pH}$ ini juga sesuai dengan $\mathrm{pH}$ saliva normal yaitu pH 6,3-7,3.

\section{Kesimpulan}

Buccal film salbutamol sulfat dapat dibuat dengan variasi perbandingan HPMC K15M:Na-CMC yaitu 1:2; $1 ; 1$ dan 2;1. Semua formula memiliki karakterisasi yang tidak jauh berbeda yaitu transparan, memiliki daya tahan lipat yang ideal serta $\mathrm{pH}$ yang sesuai.

\section{Ucapan Terima Kasih}

Kami mengucapkan terima kasih yang sebesarbesarnya kepada Kemristekdikti melalui Simbelmawa yang telah mendanai Program Kreativitas Mahasiswa (PKM) pada tahun 2018.

\section{Daftar Pustaka}

1. Burns MAC, Wells BG, Schwinghammer TL, Malone PM, Kolesar JM, DiPiro JT. Pharmacotherapy Principles $\&$ Practice. $4^{\text {th }}$ Edition, New York: McGraw-Hill Education, 2016.

2. To T, Stanojevic S, Moores G, Gershon AS, Bateman ED, Cruz AA, Boulet LP. Global asthma prevalence in adults: findings from the cross-sectional world health survey. BMC Public Health., 2012, 12(204); 1-8.

3. Ferkol T, Schraufnagel D. The Global Burden of Respiratory Disease. Ann. Am. Thorac. Soc., 2014, 11(3); 404-406.

4. Kementrian Kesehatan RI. 2013. Riset Kesehatan Dasar. Jakarta: Badan Penelitian dan Pengembangan Kesehatan, 2013.
5. Katzung, B.G., Masters, S.B., dan Trevor, A.J. 2012. Farmakologi Dasar dan Klinik. Edisi 12. Volume 1, Penerbit Buku Kedokteran EGC. Jakarta.

6. Badan Pengawas Obat dan Makanan. 2008. Informatorium Obat Nasional Indonesia. Badan Pengawas Obat dan Makanan Republik Indonesia. Koperpom. Sagung Seto. Jakarta.

7. Sukandar, E.Y., Retnosari A., Joseph I.S., I Ketut A.,A. Adji P.S., dan Kusnandar. 2008. ISO Farmakoterapi. PT. ISFI Penerbitan. Jakarta.

8. Burns, M.A.C., Wells, B.G., Schwinghammer, T.L., Malone, P.M., Kolesar, J.M., Rotschafer, J.C., dan DiPiro, J.T. 2008. Pharmacotherapy Principles \& Practice. The McGraw-Hill Companies. New York.

9. Singh, S., Soni, R., Rawat, M.K., Jain, A., Deshpande, S.B., Singh, S.K., dan Muthu, M.S. 2010. In Vitro and In Vivo Evaluation of Buccal Bioadhesive Films Containing Salbutamol Sulphate. Chem. Pharm. Bull. 58(3) : 307311.

10. Sweetman, S.C. 2009 Martindale: The Complete Drug Reference. $36^{\text {th }}$ Edition, Pharmaceutical Press. London.

11. Kumar, G.S.S., Shivakumar H.G., Kumar, T.M.P, Yogananda R., dan Charyulu, R.N. 2010. Formulation and In-Vitro Evaluation of Buccoadhesive Compacts of Salbutamol Sulphate. Int. J. Drug Dev. \& Res. 2(4) : 912920.

12. Gotalia, F. 2012. Formulasi Buccal film Mukoadhesif dengan Pragelatinasi Pati Singkong Ftalat sebagai Polimer Pembentuk Film. Skripsi. Universitas Indonesia, Depok.

13. Ansari, M., Sadarani, B., dan Majumdar, A. 2017. Optimization and Evaluation of Mucoadhesive Buccal Film Loaded with Resveratrol. Journal of drug Delivery Science Technology : 1-22

14. Deepthi, B., Mounika, M., dan Kumar, Y. S. 2017. Formulation and Evaluation of Salbutamol Sulphate Sublingual Films. Int. J. Pharm. Sci. Nanotech. 10(5) : 3836-3843. 